\title{
The Prominence of Reading and Writing Skills with Reference to R.L. Stevenson and His Words
}

\author{
Dharinee Arvind and P Harshini \\ Department of English, Dr. M. G. R. Educational and \\ Research Institute, Maduravoyal, Chennai, India
}

\begin{abstract}
Communication may be in the form of oral or written. This research article brings an interface between writing and reading skills. In some way, learning and reading were linked with one other. Both the skills go hand in hand. It aims to bring the experience through reading and writing by reading the text printed material and bringing out the writing skills pattern. It is vital to see no misinterpretation of the messages; else, the readers might not comprehend the text's points. Writing is also a form of communication, and once written, it remains permanent for a long time; meaning does not change. Knowledge can be enlarged by writing skills too. Learning to write the range of genres, audiences, and purpose of all the writing is a valid starting point for the readers what they have learned, which helps the readers for their future employment.
\end{abstract}

KEY WORDS: INTERFACE, WRITING SKILLS, EXPERIENCE, PATTERN, MISINTERPRETATION, COMMUNICATION.

\section{INTRODUCTION}

Writing gives numerous ideas as and when one writes. It also gives us access to an individual's knowledge. Sometimes, one may feel writing may be unexciting initially, but automatically, one develops interests in writing skills when you start. If one is an expert at hand, then he/she can go to any extent of writing skills. The idea of writing can be sketched back to over thousands of years ago but remains constant as writing skills are an act of recording. One's thinking and changing perspective is drawn from one's mind, so by saying this, if he/she feels that writing is a tedious task, it is necessary to change that perspective from negative to positive because writing is a form of expressing thoughts hatred or happiness. R.L. Stevenson says in his report too that he wrote it for no use in the beginning, but then he mentioned that he kept on writing just for practicing.

Oral communication differs from written communication. In verbal communication, the listener can make out just

Biosc Biotech Res Comm P-ISSN: 0974-6455 E-ISSN: 2321-4007

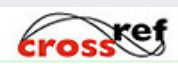

Identifiers and Pagination

Year: 2021 Vol: 14 No (8) Special Issue

Pages: $94-97$

This is an open access article under Creative

Commons License Attribn 4.0 Intl (CC-BY).

DOI: $h t t p: / / d x . d o i . o r g / 10.21786 / b b r c / 14.8 .23$ by listening but is written; the text must be understood to read and reflect the message. By writing alone, one can bring out the replication of thinking. Any person can interpret the message only when the text is written. Once writing started, it should be concise and purposeful. Only in writing alone, suggestions and comments are valuable. Even though all the readers change the writing skills in different ways, the text remains the same. A small change in the text also does not reflect in the text as it remains permanent. Some people even take writing skills as creative writing too. If the report is written in advance, it can be altered at a later stage. Each individual brings their own time to write their articles. Formerly when the research article or any other subject has been written down, they can be changed or modified later. As earlier said, this writing had been recorded; it can be later ascertained. Writing skills is for deep study and dealing with the stories to note financial transactions and record history. While written communication is more accessible than reading or oral, it leaves a perennial impression on the readers.

There are many categories for writing skills, of those in creative writing, which many people adhere to. Each script differs from one to one. There are specific rules or writing units if there should be correspondence in writing in the present system. These writings may not be in written form alone; instead, they can be in graphical representation by communicating through words and 
symbols. Different languages have the same script. Sometimes by the sound of the terms, these scripts can be written. Reading and writing essentially depend upon the same skill. There are some writing tips which we can adopt to bring in the reputation of the writing skill. People or the readers don't read everything written in the text; hence, only the highlighted points are sufficient to write the text. The familiar words can be omitted, for example, "extremely," "really." How does one nurture the art of writing? The answer is passion. The writers are supposed to write their work on their subject. When the paper is filled with actual words spontaneously coming out from our hearts, the passion for writing progresses.

\section{METHODS}

The study was designed to take the survey to determine the numbers included in reading with connection to writing skills. It, too, showed the importance that writing is essential in one of the four skills.

Participant: The sources for conducted for this survey are the ten people. There were from different departments, but most of them were from the literary group of people.

Data Collection: The data was collected through online mode. As technology improved rapidly, and due to the pandemic situation, the researcher adopted an online method that is the question forms was directly uploaded on the site. To get accurate figures, the data was collected decorously.

Data Analysis: The data was collected based on the numbers given by the students. There are some methods to adopt while taking the survey. It was taken from a single group of people who were from literary and nonliterary groups.

\begin{tabular}{|c|c|c|c|c|c|c|}
\hline Sl.No & $\begin{array}{l}\text { Writing and } \\
\text { Reading Skills }\end{array}$ & Always & Often & Sometimes & Rarely & Never \\
\hline 1 & $\begin{array}{l}\text { While writing, it is necessary to show } \\
\text { the importance of the skill. }\end{array}$ & 7 & 5 & 1 & 2 & 0 \\
\hline 2 & $\begin{array}{l}\text { A writer must leave a lasting impression } \\
\text { to develop a further interest in writing. }\end{array}$ & 4 & 4 & 7 & 0 & 0 \\
\hline 3 & $\begin{array}{l}\text { The possibility of misinterpretation can occur } \\
\text { while reading the same message. }\end{array}$ & 3 & 3 & 7 & 1 & 1 \\
\hline 4 & Ordinary people need writing skills. & 5 & 5 & 5 & 0 & 0 \\
\hline 5 & $\begin{array}{l}\text { Since the facial expression cannot be seen, } \\
\text { hidden meaning cannot be understood. }\end{array}$ & 5 & 6 & 3 & 1 & 0 \\
\hline 6 & $\begin{array}{l}\text { Immediate feedback is statutory while } \\
\text { writing and reading. }\end{array}$ & 8 & 2 & 4 & 1 & 0 \\
\hline 7 & Writing also gives access to knowledge. & 9 & 2 & 3 & 1 & 0 \\
\hline 8 & Readers learn by writing and reading. & 6 & 5 & 3 & 1 & 0 \\
\hline 9 & Both writing and reading reinforces one another. & 4 & 6 & 3 & 2 & 0 \\
\hline 10 & $\begin{array}{l}\text { Successful writing is all about trust- } \\
\text { worthy and authority. }\end{array}$ & 4 & 9 & 1 & 1 & 0 \\
\hline
\end{tabular}

Findings and Discussion: This study was used by the indirect method that is the 'Questionnaire,' to report the research question. Also, technology has vastly improved. It was thought to have an indirect manner. There were around ten questions centered on the writing style of RL Stevenson. The questions consisted of specific department students. The sample population was from the English medium only.

Robert Louis Stevenson (1850-1894): Robert Louis Stevenson was an essayist, poet, and author of fiction and travel books. His interest was in travel writing, and his most famous paper was 'Treasure Island, 'Kidnapped.' James preferred "Treasure Island" more than other articles. His main concentration was only English critics. Most of his writing was solely based on travel and literature. He loved traveling around the world. He would write all kinds of fictional essays or poems. From 1888 to 1990 , as he kept traveling, he would admire nature, explore and later turned his writing from romance to adventure. He toured from pacific voyages to Samoa Island. He composed two ballads on Pacific voyages and Samoa Islands. As Stevenson kept himself busy, he would travel around and write whatever he saw everywhere. Stevenson came up with dramatic ideologies that he had played in many parts as and when he toured. He had virtually come up with many genres in literary fields. His writing would be primarily based on his works. His words in the writing process would tempt him.

His ideology was entirely different. His interest was simply in traveling, but those who had a genuine interest in writing gave some of his best advice to outcome their best: Read the best authors, the objective should be simplicity, and always best to work on our style. Stevenson's thought was still abiding by the truth only; 
else, their work will not succeed. Every writer is pushing their effort into writing. All writers or poets, also for that matter, were very genuine in their work. He holds an exceptional place in the heart and minds of many writers. It is also well-known that Stevenson's introduction to natural and grown-up books. When a particular reader starts reading about RL Stevenson, he/she spontaneously knows a lot of information about him. He worked with not only one but at the same time worked with other subjects too. One may say that Stevenson's work also displays his craft in writing. He shows the importance of both reading and writing. Like the author, he worked a lot for himself; would have a copy to himself; when he felt unwell, he ensured that his work was completed within the stipulated amount of time.

\begin{tabular}{|c|c|c|c|c|c|c|}
\hline Sl.No & Writing And Reading Skills & Always & Often & Sometimes & Rarely & Never \\
\hline 1 & $\begin{array}{l}\text { While writing, it is necessary to } \\
\text { show the importance of the skill. }\end{array}$ & 7 & 5 & 1 & 2 & 0 \\
\hline 2 & $\begin{array}{l}\text { A writer must leave a lasting impression } \\
\text { to develop a further interest in writing. }\end{array}$ & 4 & 4 & 7 & 0 & 0 \\
\hline 3 & $\begin{array}{l}\text { The possibility of misinterpretation can } \\
\text { occur while reading the same message. }\end{array}$ & 3 & 3 & 7 & 1 & 1 \\
\hline 4 & Ordinary people need writing skills. & 5 & 5 & 7 & 0 & 0 \\
\hline 5 & $\begin{array}{l}\text { Since the facial expression cannot be seen, } \\
\text { hidden meaning cannot be understood. }\end{array}$ & 5 & 6 & 3 & 1 & 0 \\
\hline
\end{tabular}

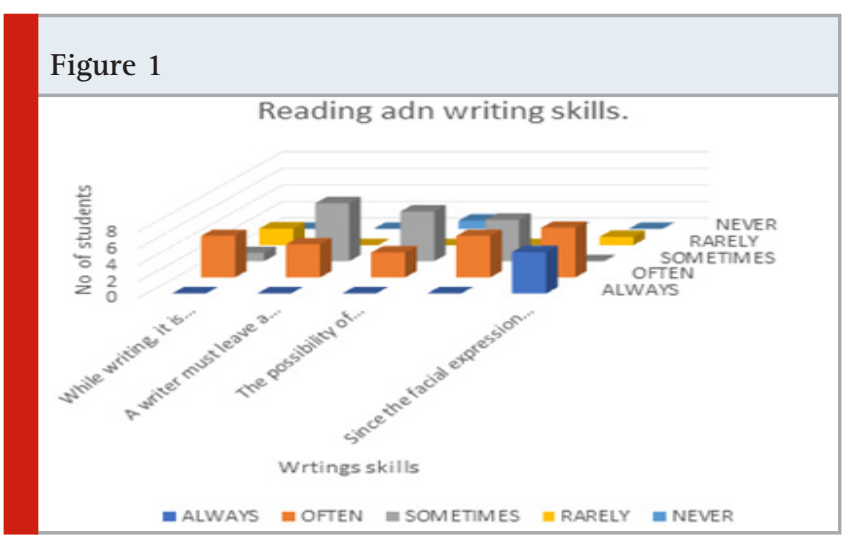

He says that his books are his refuge whenever he was in much trouble to read and write. Sometimes, the messages delivered, maybe children's comic books, Highland, feel worth describing anything. For Stevenson, it was a part of the training. It was thought that the essential component was the training, and the same he converted into art, he had put in so much effort to get the profit for his works. He would see things from a perspective angle. As soon as he read a book that contented him, he had an effect that he rendered propriety in which there was complete happiness in his style. All he wanted is to sit down along the riverside and set himself to his class.

\begin{tabular}{|c|c|c|c|c|c|c|}
\hline Sl.No & Writing And Reading Skills & Always & Often & Sometimes & Rarely & Never \\
\hline 6 & $\begin{array}{l}\text { Immediate feedback is statutory } \\
\text { while writing and reading. }\end{array}$ & 8 & 2 & 4 & 1 & 02 \\
\hline 7 & $\begin{array}{l}\text { Writing also gives access } \\
\text { to knowledge. }\end{array}$ & 9 & 2 & 3 & 1 & 0 \\
\hline 8 & $\begin{array}{l}\text { Readers learn by } \\
\text { writing and reading. }\end{array}$ & 6 & 5 & 3 & 1 & 0 \\
\hline 9 & $\begin{array}{l}\text { Both writing and reading } 4 \\
\text { reinforces one another. }\end{array}$ & 6 & 3 & 2 & 0 & \\
\hline 10 & $\begin{array}{l}\text { Successful writing is all about trust- } \\
\text { worthy and authority. }\end{array}$ & 4 & 9 & 1 & 1 & 0 \\
\hline
\end{tabular}

There are some technical elements while displaying in his works. He had an important note and would always find the exact word. Stevenson fights back till the end during his reading time. He tried to read specific phrases maybe but became unsuccessful in his reading. But Stevenson never regretted this; instead, he took it as a positive note and learned it as a practice. He has played in many parts from ape to Hazlitt, to lamb, and Wordsworth. 


\section{Figure 2}

\section{OFTEN}

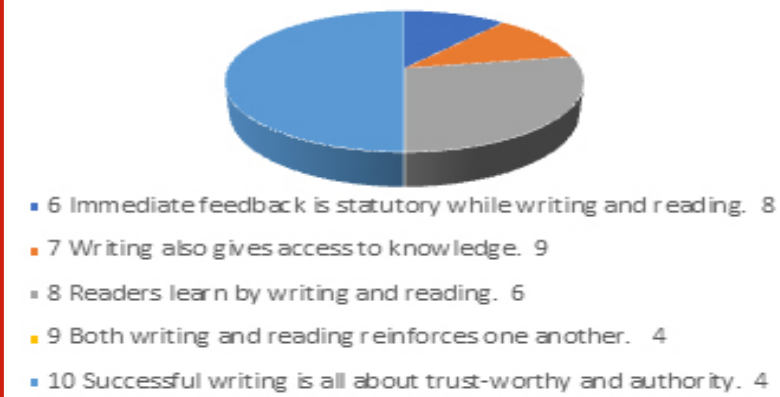

There was never an option called being liked or unlikethe only way to learn whether it has been beneficial for my study or not. Even Keats was astonished. In this period, all men could trace and learn more. It is an excellent point that these intimations still shine beyond every student's inevitable model. Let an individual try, try and become unsuccessful; Failure is the stepping stone to success. His works were like by himself, and when it was completed, he wouldn't like his work. He would regret to show his friends, and even if he did, there were only confidants friends because he had chosen that kind of friend who was very plain with him. Stevenson's style of writing was easy to comprehend, and it was acknowledgeable. It was easy to get all the points across his writing. While Stevenson was at the University, he trained himself to be a writer by replicating the style of other prominent writers like William Hazlitt and Daniel Defoe, among others.

His literary career took place in the Victorian Era. Some of his works are based upon his real life-experiences that happened in his life. Stevenson never bothered about whether it was related to him or not. But his life was tragic. His life was transformed from good to bad. For many writers, their life would be different. Sometimes it would change from bad to good, but it was from good to bad for Stevenson. He went through all the failure, depression as well as success. Later on, he got his works published, after which they became successful published works. Since he was a traveler, he wrote most of his books while traveling. In that way, his first books on his journeys were 'An Inland Voyage (1878) and 'Travels with a Donkey in the Cavennes (1879) on his way to France. Stevenson's style was never imitated. Some of his novels had specifications in his writing style. He portrayed his difference in style of writing in each of his novels.

For instance, one of Stevenson's novel 'The Strange Case of Dr. Jekyll and Mr. Hyde, is about his life judgements that we come across in our day-to-day life. In this novel, he reflects the Victorian Culture, the concept of good and evil. It is said to be a historical novel also. Next comes Stevenson's big point; he says art is made into patterns. The primary function of writing is communication,
Stevenson says even in the music the sounds and pauses are made in time, by this he says that this is also one kind of art. A Writer brings out the varieties of art in them and poses their skill in writing skill. A difference in Stevenson's style in his every work can be seen. What is apt or correct to the point is choice of words is applied. Some of them think that why style is important in writing? It is individuality own perception of knowledge and specification of the idea.

\section{CONCLUSION}

Reading and writing skills are not only meant for academic purposes but also general skills. Everyone must know the link between reading and writing. Both of the skills are important, especially in research work. Writing skill is a particular design that enables the writers to think critically and write using creativity. Writing and reading do not come out suddenly unless you attempt to practice and make it a routine. Generally, in an academic institution, students fear what each wants to say because they don't have anything to say. Some may have the courage to read but not to write. Many think that writing is complicated because it is not an immediate process. But as one approaches writing, one must feel empowered by knowing that it is a different writing phase. It is advantageous in all skill levels, even at schools, colleges, and even institutions. It is not towards an end-product.

It is a continuous process and adds creativity to every writer. Sometimes our mind becomes blank, but then, it automatically goes into what one wants to say or do due to the mind's immediate action. Reading depends upon the mind of the readers. Also, there are different types of readers, ardent readers, slow-readers, or reading to develop the skill in one's way. There should always be a commitment in reading and writing to avoid any fault in the future. Stevenson also stresses reading and writing skills because he loved travelling. Even during his travel, he would describe what he saw, so he wanted the writers and readers to simultaneously up-bring both of the skills.

\section{REFERENCES}

Balfour,Graham;The Life of Robert Louis Stevenson [1906], London

Colley Ann : Wiley Online Contributors;Victorian Literature

David Daiches, RL Stevenson and his world, University of Sussex, England.

Earnest Mahew; Selected Letters of Robert Louis Stevenson;[2001] New haven and London, Yale University

Lang,Andrew [1911], The works of Robert Louis Stevenson; Chatto and Windness

Stephen; Writers of transition(review), Sussex

Stephenson[1850-1894],Childhood and Schooling;0xford Dictionary of National Biography, Oxford University. 